\title{
The Ameliorative Effects of Caffeic Acid Phenethyl Ester in Cisplatin-Induced Nephrotoxicity: Assessment of the Oxidative Stress an Inflammation
}

\author{
Los Efectos de Mejora del Éster Fenetílico del Ácido Cafeico en la Nefrotoxicidad \\ Inducida por Cisplatino: Evaluación del Estrés OxidativoI y la Inflamación
}

Tayfun Ceylan ${ }^{1,4}$; Emin Kaymak²; Ali Tugrul Akin ${ }^{3} \&$ Birkan Yakan $^{4}$

CEYLAN, T.; KAYMAK, E.; AKIN, A. T. \& YAKAN, B. The ameliorative effects of caffeic acid phenethyl ester in cisplatin-induced nephrotoxicity: Assessment of the oxidative stress and inflammation. Int. J. Morphol., 39(2):612-618, 2021.

SUMMARY: The aim of this study is to determine the potential therapeutic effects of CAPE in CP-induced nephrotoxicity in rats. Cisplatin (CP) is an antineoplastic chemotherapeutic used for treatment of many cancer types but its applications may induce nephrotoxicity. Caffeic acid phenethyl ester (CAPE) is an active component of propolis and it has several important physiological activities. Rats were divided into four groups: Control, CAPE $(10 \mu \mathrm{mol} / \mathrm{kg} / \mathrm{i} . \mathrm{p}), \mathrm{CP}(7 \mathrm{mg} / \mathrm{kg} / \mathrm{i} . \mathrm{p})$, and CP+CAPE $(7 \mathrm{mg} / \mathrm{kg} / \mathrm{i} . \mathrm{p}, \mathrm{CP}$ and $10 \mu \mathrm{mol} / \mathrm{kg} / \mathrm{i} . \mathrm{p}, \mathrm{CAPE})$. After administrations, animals were sacrificed, and kidney tissues were extracted. Histopathological changes were evaluated and TNF- $\alpha$ and IL- 6 immunostaining were performed. Moreover, tissue SOD, CAT and MDA levels were measured by ELISA assay to assessment of oxidative stress and lipid peroxidation. CP group showed histopathological deterioration compared to the Control group and CAPE treatment attenuated this damage. When compared with Control and CAPE group, an increase in TNF- $\alpha$ and IL-6 immunoreactivities and tissue MDA levels were observed in the CP group while a decrease in tissue SOD and CAT levels were detected. Furthermore, an improvement was observed in the $\mathrm{CP}+\mathrm{CAPE}$ compared to the $\mathrm{CP}$ group. We suggest that CAPE can be used as a therapeutic agent to attenuate the toxic effects of cisplatin, thanks to its antioxidant and anti-inflammatory properties.

KEY WORDS. Cisplatin; Caffeic acid phenethyl ester; Inflammation; Oxidative stress.

\section{INTRODUCTION}

As one of the most lethal diseases, cancer is widely characterized by uncontrolled cell proliferation and division under the control of several genetic and environmental factors (Howlader et al., 2019). Nowadays, the long-term survival ratios of the patients and their life quality have increased because of the increasing success rate of chemotherapy. However, chemotherapeutics may cause serious damage in healthy organs because their mechanism of action could not be completely understood (Patel \& Kaufmann, 2012). Chemotherapeutics have several side effects and nephrotoxicity is one of the most commonly known side effects of them (Lampe et al., 1997).

Cisplatin (CP), also known as CPdiamminedichloroplatinum-II, is white or dark yellow-orange crystalline powder at room temperature. $\mathrm{CP}$ is used for the treatment of many cancer types such as lung, breast, ovarian, testicle and head and neck cancers thanks to its anticancer activity. Thus, it is the most commonly known chemotherapeutic among chemotherapy drugs (Dasari \& Tchounwou, 2014; Hanif \& Hartinger, 2018). Although CP is used in many cancer treatments, it has many side effects including neurotoxicity, nephrotoxicity, hepatotoxicity, gonadotoxicity (Lu et al., 2006; Santos et al., 2008; Melli et al., 2008; Quintanilha et al., 2017; Kohsaka et al., 2020).

Several studies have reported that CP chemotherapy lead to oxidative stress via excessive formation of reactive oxygen species (ROS), lipid peroxidation, inflammation and apoptosis in kidney tissue (Al Fayi et al., 2020; Ismail et al., 2020; Liu et al., 2020). ROS cause the production of hydrogen peroxide (H2O2) and hydroxyl radicals $(\mathrm{OH})$ that can attack

\footnotetext{
${ }^{1}$ Cappadocia University, Cappadocia Vocational School, Department of Medical Services and Technique, Pathology Laboratory Techniques Pr., Nevsehir, Turkey.

${ }^{2}$ Yozgat Bozok University, Faculty of Medicine, Histology-Embryology Department, Yozgat, Turkey.

${ }^{3}$ Erciyes University, Science Faculty, Biology Department, Kayseri, Turkey.

${ }^{4}$ Erciyes University, Faculty of Medicine, Histology-Embryology Department, Kayseri, Turkey.

Tay fun Ceylan, 0000-0002-0917-0378. Emin Kaymak, 0000-0002-3818-2693.

Ali Tugrul Akin, 0000-0002-1408-8571. Birkan Yakan, 0000-0002-5456-4579.
} 
DNA, oxidize it and finally trigger apoptotic pathways in both normal and tumoral tissue cells (Al-Dalaen \& AlQtaitat, 2014). Moreover, oxidative stress leads to lipid peroxidation (LPO) in the cell through the production of reactive oxygen species (ROS). The endogenous antioxidant system (glutathione peroxidase, superoxide dismutase and catalase) aims to neutralize ROS. However, excessive formation of ROS consumes endogenous antioxidants and leads to peroxidation of membrane lipids and increases the oxidation of proteins (Kumar et al., 2015). Formation of excessive reactive oxygen species (ROS), the debilitation of the antioxidant defense system and lipid peroxidation of bio-membranes may cause the upregulation of inflammatory pathways and excessive releasing of pro- and antiinflammatory cytokines such as Tumor Necrose Factor-alpha (TNF- $\alpha$ ) and Interleukin-6 (IL-6). Cytokines, which are polypeptides produced and secreted by various cell types, regulate immune and inflammatory events, including cell growth, healing and systemic response to inflammation. Thus, disequilibrium between cytokine expressions may induce necrosis and apoptosis (Noronha et al., 1995).

Caffeic acid phenethyl ester (CAPE) has been a commonly used intraditional medicine in Asia for thousand years. CAPE is an active phenolic component of propolis in the hives of honeybees and it has several important physiological activities such as antitumoral, antiproliferative, anti-inflammatory, antineoplastic, and antioxidant properties. The content of propolis shows a common complex structure and it comprises waxes, resin, and volatiles. Moreover, the whole content varies according to the geographical area. The resin component of propolis includes phenolic acids, their esters, terpenes, flavonoids, fatty acids, steroids, aromatic aldehydes, and alcohols. CAPE is the most commonly used and known substance among these components of propolis (Burdock, 1998).

In this study, we aimed to investigate the potential therapeutic effects of CAPE on CP-induced nephrotoxicity in rats by investigating oxidative stress and inflammation. For this purpose, a significant kidney damage was induced by $\mathrm{CP}$ and CAPE administrations were performed to eliminate the hazardous effects of CP. Furthermore, histopathological, immunohistochemical and biochemical changes were evaluated to determine the effects of $\mathrm{CP}$ and CAPE.

\section{MATERIAL AND METHOD}

Experimental design. The experimental protocol of this study was accepted by the Erciyes University's Experimen- tal Animal and Local Ethics' Committee with number 15/ 059/2015. In this study, all the animals received human care according to standard guidelines. Thirty-eight male Wistar albino rats (9 weeks old, weighing 200-250 g) were obtained from Hakan Cetinsaya Experimental and Clinic Research Center, Erciyes University, Kayseri, Turkey. Rats were kept at room temperature $\left(20-24^{\circ} \mathrm{C}\right)$ for 12 hours light/12 hours dark cycle and ambient humidity for the duration of the experiment. Standard chow and tap water were given to animals ad libitum. At the beginning of the experiment, the rats randomly divided into five groups as follows; The Control group $(n=8)$ were untreated rats, the CAPE group $(\mathrm{n}=10)$ administered $10 \mu \mathrm{g} / \mathrm{kg} / \mathrm{i} . \mathrm{p}$ for 12 days (Ozen et al., 2004), the CP group ( $\mathrm{n}=10)$ given $7 \mathrm{mg} / \mathrm{kg} / \mathrm{i} . \mathrm{p}$ $\mathrm{CP}$ on the $7^{\text {th }}$ day of the experiment (Sadeghi et al., 2020) and the CP+CAPE group $(\mathrm{n}=10)$ injected with $7 \mathrm{mg} / \mathrm{kg} / \mathrm{i} . \mathrm{p}$ $\mathrm{CP}$ on the $7^{\text {th }}$ day of the experiment and CAPE for 12 days. Experiment continued for 14 days. At the end of the experiment, animals were anesthetized with $30 \mathrm{mg} / \mathrm{kg}$ ketamine and $4 \mathrm{mg} / \mathrm{kg}$ xylazine and they were sacrificed. After sacrifice, kidney tissues were extracted from the animals for the histopathological, immunohistochemical and biochemical examinations. For later biochemical assays, tissue samples were kept at $-80^{\circ} \mathrm{C}$.

Histopathological evaluation. After sacrificing the animals, the kidney tissues were extracted and were fixed in $4 \%$ formaldehyde for histological examination. Following dehydration and clearing, they were embedded in paraffin. Sections were stained with periodic acid Schiff (PAS), photographs were taken with a light microscope (Olympus BX51, Center Valley, PA). For histopathological scoring, the following criteria were used; hemorrhage, glomerular degeneration, tubular obstruction, tubular epithelial shedding. Scoring was conducted as follows: $0=$ not at all, $1=0-25 \%, 2=26-45 \%, 3=46-75 \%$, and $4=$ 76-100\% (Ozbilgin et al., 2016).

PAS staining. Paraffin sections were incubated at $58{ }^{\circ} \mathrm{C}$ for 2 hours. After deparaffinization and rehydration, they were washed with water. They were kept in periodic acid for 10 to $15 \mathrm{~min}$ and washed with water. Sections were placed in the Schiff solution for $20 \mathrm{~min}$ at room temperature in the dark place. After washing under the water, they were exposed to hematoxylin solution. Acid-alcohol was applied, and they were washed and examined under the microscope after dehydration and clearing.

Immunohistochemistry. Immunohistochemistry method was used to investigate TNF- $\alpha$ and IL-6 immunoreactivities in the kidney tissues. $5 \mu \mathrm{m}$ sections were gotten from liver tissues embedded in paraffin blocks. The sections were kept in the oven at $60{ }^{\circ} \mathrm{C}$ for at least $2 \mathrm{hr}$ so that the paraffin 
melted. The tissues were deparaffinized and rehydrated using xylene and alcohol series. Sections were taken into 0.01 M citrate buffer and heated in microwave oven at $350 \mathrm{~W}$, consequently antigen retrieval was obtained. Then, sections were kept three times in phosphate buffered saline (PBS) for $5 \mathrm{~min}$. The sections were kept in $3 \%(\mathrm{w} / \mathrm{v}) \mathrm{H}_{2} \mathrm{O}_{2}$ for 10 $\mathrm{min}$ to block endogenous peroxidase activity. After washing again 3 times in PBS, ultra $v$ block solution was added to the tissues and kept in the tank for 5 min. After then, TNF$\alpha$ (Cat. No: E-AB-52065, Elapscience, USA) and IL-6 (Cat. No: E-AB-40073, Elapscience, USA) antibodies were added to the tissues and incubated overnight at $4{ }^{\circ} \mathrm{C}$. The following morning, the tissues were washed again 3 times with PBS and the secondary antibody (TA-125-HDX, Thermo Fisher Scientific, Waltham, MA, USA) was instilled for $10 \mathrm{~min}$ at room temperature. After washing with PBS, the immunoreaction was amplified using the streptavidin-avidin-peroxidase complex and the sections were visualized using 3,30-p-diaminobenzidine tetrahydrochloride (TA-060-HDX, Thermo Fisher Scientific, Waltham, MA, USA) lightly counter-stained with Gill hematoxylin. For the final step, increasing alcohol serial concentrations were used to remove water, the sections were then passed through xylene, and finally, they were covered with an entellan. Images were taken using light microscope. Image J program was used to evaluate antibody expressions (Karabulut et al., 2016).

ELISA assay. The kidney tissue superoxide dismutase (SOD), catalase (CAT) and malondialdehyde (MDA) levels were measured by using Enzyme-linked Immunosorbent Assay (ELISA) method. For this purpose, kidney samples stored $-80^{\circ} \mathrm{C}$ were used. The samples were homogenized on ice and then centrifuged to remove supernatants. $150 \mu \mathrm{L}$ of the supernatant were taken into Eppendorf tubes separately for each group. For analysis, Superoxide dismutase (SOD) (Cat. No: 201-11-0169, Sun Red Biological Technology), Catalase (CAT) (Cat. No: 20111-5106, Sun Red Biological Technology) and Malondialdehyde (MDA) (Cat. No: Cat. No: 201-11-0157, Sun Red Biological Technology) ELISA kits were used. In standard preparation, standard diluent was added to 5 tubes. Then $120 \mu \mathrm{L}$ of standard solution were added to the first tube and mixed. After then, $120 \mu \mathrm{L}$ from the previous tube were added to the other 4 tubes respectively. $40 \mu \mathrm{L}$ of 150 $\mu \mathrm{L}$ from the supernatant were added to the samples section. Then, we added $10 \mu \mathrm{L}$ of antibody to the samples. We added $50 \mu \mathrm{L}$ of streptavidin HRP to both samples and standard section. Then, incubated $60 \mathrm{~min}$ at $37^{\circ} \mathrm{C}$ oven. We washed plate five times and added chromogen solution A, B. We put it in a $37{ }^{\circ} \mathrm{C}$ oven for $10 \mathrm{~min}$. Afterwards, we added stop solution and measured the optical density (OD) under 450 $\mathrm{nM}$ wavelength within $10 \mathrm{~min}$.
Statistical Analysis. All statistical analyses were carried out by using GraphPad Prism version 7.00 for Mac, GraphPad Software, La Jolla, California, USA. D'Agostino Pearson omnibus test was used to identify the normal distribution of the data. In the case of normal distribution, quantitative variables were compared using one-way analysis of variance (ANOVA) and Tukey's post-hoc test. Kruskal Wallis test and Tukey's post-hoc test were used for comparing the quantitative with the abnormal distribution. The data were expressed as the mean of normalized data \pm standard deviation of the mean. $p<0.05$ was considered as statistically significant.

\section{RESULTS}

Histopathological findings. Periodic acid Schiff staining were performed to investigate the histopathological changes in the kidney tissue. Healthy kidney tissue was observed in the Control and CAPE groups. In the $\mathrm{CP}$ group, glomerular degeneration, microvilli reduction and tubular dilatation were observed and a significantly increase was observed in kidney damage compared to the Control group $(p<0.0001)$. There was a statistically significant decrease in the kidney damage in $\mathrm{CP}+\mathrm{CAPE}$ group compared to $\mathrm{CP}(p<0.0001)$. PAS staining of all experimental groups and statistical analysis of the histopathological score were given in Figure 1.

Immunohistochemical findings. Immunohistochemical staining was performed by using the avidin-biotin method to determine the kidney tissue expressions of TNF- $\alpha$ and IL-6. Immunohistochemical examinations demonstrated the presence of TNF- $\alpha$ and IL-6immunoreactivity in the kidney tissue of all experimental groups. The TNF- $\alpha$ and IL- 6 expressions in the kidney of CAPE group were similar to those in the Control group. Especially, TNF- $\alpha$ and IL-6 immunoreactivity were considerably increased in kidney tissue in CP group. However, TNF- $\alpha$ and IL- 6 expressions of $\mathrm{CP}+\mathrm{CAPE}$ group were substantially less compared to those in the CP group. Figure 2 shows the immunostaining of TNF- $\alpha$ and IL- 6 and statistical analysis of the immunoreactivity measurements in experimental groups.

Biochemical findings. The results of the levels of the antioxidant enzymes measured by ELISA assay in the kidney tissue and statistical analysis of them are shown in Table I. Kidney tissue SOD and CAT levels showed a tendency to decrease in the CP group compared to the Control and CAPE groups $(p>0.05)$. However, SOD and CAT levels in the $\mathrm{CP}+\mathrm{CAPE}$ group were higher than those in the $\mathrm{CP}$ group. MDA level significantly increased in the $\mathrm{CP}$ group compared to the Control group $(p<0.001)$ while it significantly decreased in the $\mathrm{CP}+\mathrm{CAPE}$ group compared to the $\mathrm{CP}$ group $(p<0.001)$ (Fig. 3 ). 


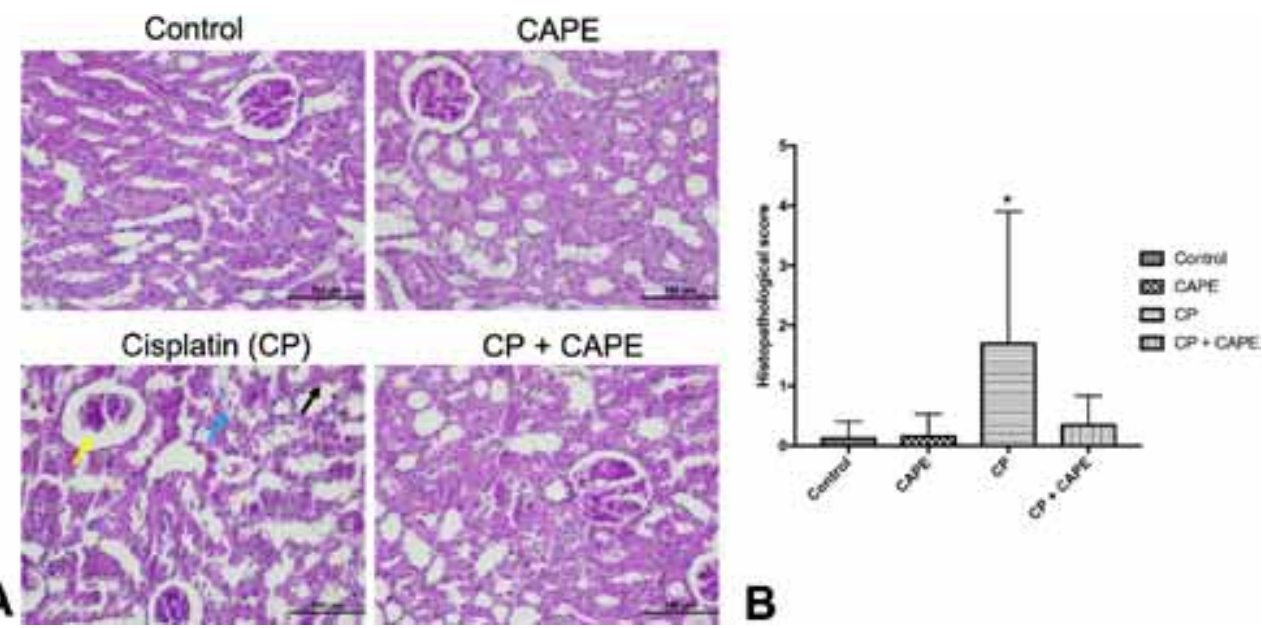

Fig. 1. Light microscopy of kidney tissues stained with PAS in experimental groups. A PAS staining of kidney tissues. Control group (untreated rats) and CAPE group (given $10 \mu \mathrm{g} / \mathrm{kg}$ caffeic acid phenethyl ester) showed normal histological structure. CP group (given $7 \mathrm{mg} / \mathrm{kg}$ cisplatin) presented glomerular degeneration (yellow arrow), microvilli reduction (blue arrow) and tubular dilatation (black arrow). $\mathrm{CP}+\mathrm{CAPE}$ group showed an improvement in terms of histopathological changes induced by CP. B Statistical analysis of the kidney damage score among experimental groups. Scale bar $=100 \mathrm{~mm}$. Abbreviations: PAS, periodic acid Schiff; CAPE, caffeic acid phenethyl ester; CP, cisplatin.
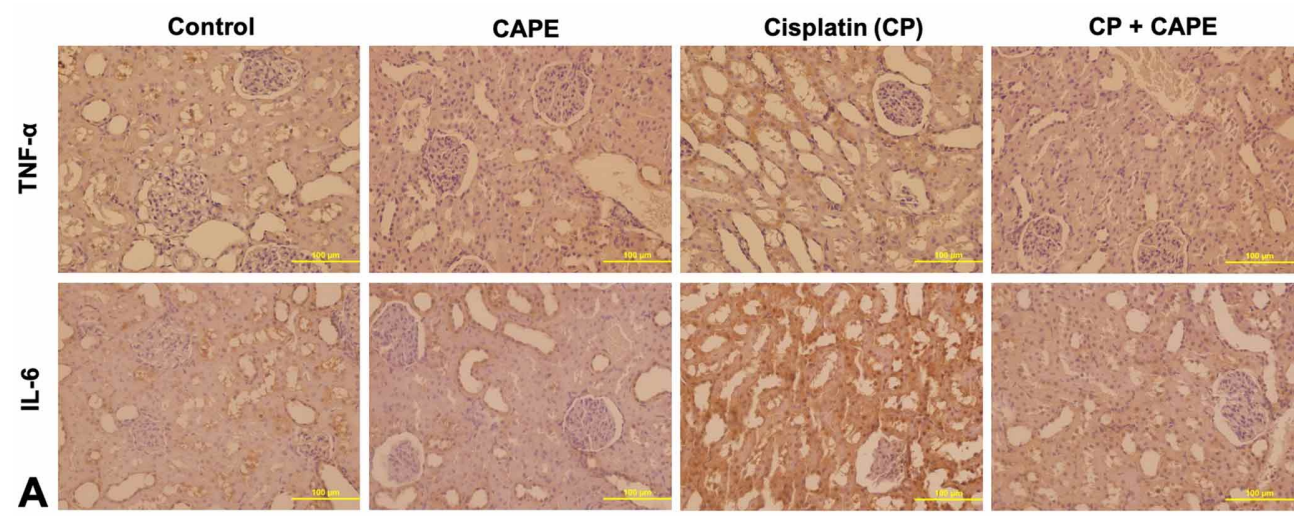

\section{B}
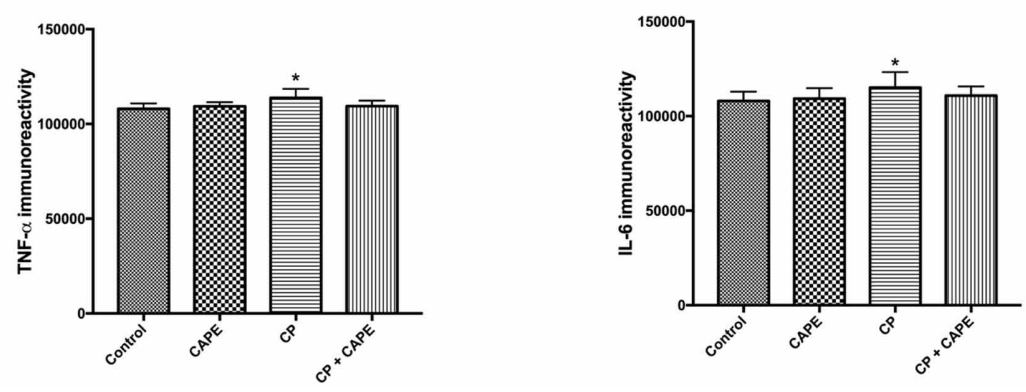

Fig. 2. A, B Immunohistochemical staining of TNF-a and IL-6 in kidney tissues and statistical analysis of the expression levels in experimental groups. A Control group $(n=8)$ and CAPE group $(n=10)$ showed weak TNF- $\alpha$ immunostaining in kidney tissue; CP group $(n=10)$, TNF-a expression increased in the kidney tissue; CP+CAPE group $(n=10)$, TNF- $\alpha$ expression decreased. Similarly, weak IL-6 immunostaining was observed in the kidney sections of Control group $(n=8)$ and CAPE group $(n=10)$; CP group ( $n=10)$, IL-6 expression increased in the kidney tissue; CP+CAPE $(n=10)$ IL-6 expressions were less when compared to the CP group. B Statistical analysis of the immunoreactivity density measurements of the TNF- $\alpha$ and IL- 6 by using Image J program. Scale bar: $100 \mathrm{~mm}$. Abbreviations: CAPE, caffeic acid phenethyl ester; CP, cisplatin; TNF- $\alpha$, tumor necrose factor-a; IL-6, interleukin-6. 

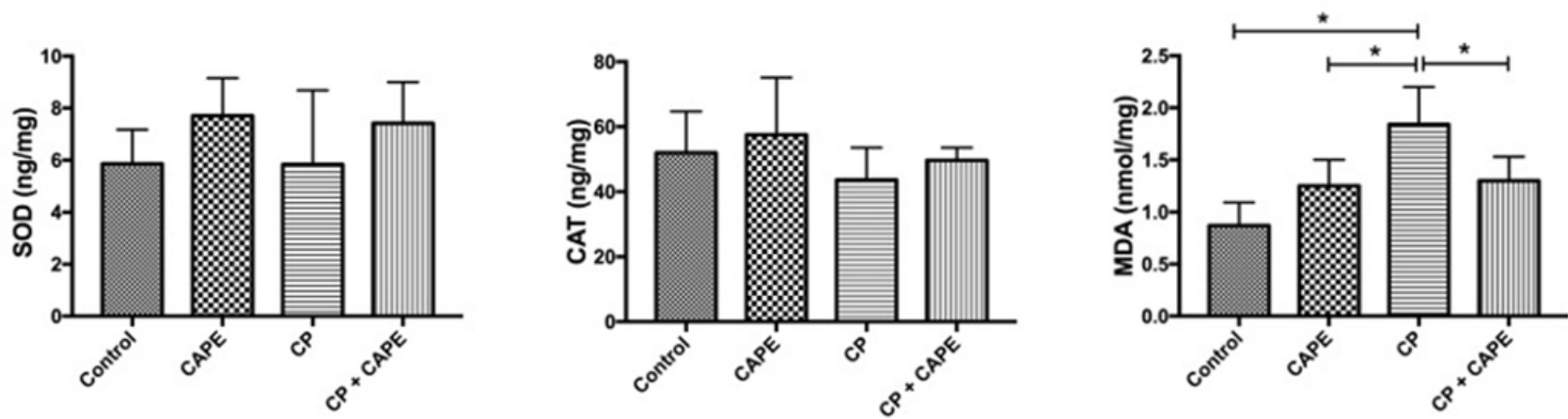

Fig. 3. Measurements of the kidney tissue SOD, CAT and MDA levels obtained by ELISA assay and statistical analysis of them in experimental groups. CP group $(n=10)$ showed decreased tissue SOD and CAT levels compared to Control group ( $n=8)$ and CAPE group $(n=10)$. Moreover, tissue MDA level significantly increased in CP group $(n=10)$ compared to Control group $(n=8)$ and CAPE group $(\mathrm{n}=10)(p<0.05)$. However, increased tissue SOD and CAT levels and significantly decreased tissue MDA levels $(p<0.05)$ were observed in $\mathrm{CP}+\mathrm{CAPE}$ group $(\mathrm{n}=10)$ compared to $\mathrm{CP}$ group. Graphs were drawn by using GraphPad Prism version 7.00 for Mac, GraphPad Software, La Jolla, California, USA. $p<0.05$ was considered as significant. Abbreviations: CP, cisplatin; CAPE, caffeic acid phenethyl ester; SOD, superoxide dismutase; CAT, catalase; MDA, malondialdehyde.

Table I. Kidney tissue levels of SOD, CAT and MDA levels among experimental groups.

\begin{tabular}{lccccc}
\hline Groups & Control $(\mathrm{n}=8)$ & CAPE $(\mathrm{n}=10)$ & $\mathrm{CP}(\mathrm{n}=10)$ & $\mathrm{CP}+\mathrm{CAPE}(\mathrm{n}=10)$ & $p$ \\
\hline SOD $(\mathrm{ng} / \mathrm{mg})$ & $5.86 \pm 1.32$ & $7.70 \pm 1.45$ & $5.84 \pm 2.85$ & $7.42 \pm 1.58$ & 0.208 \\
CAT $(\mathrm{ng} / \mathrm{mg})$ & $51.96 \pm 12.75$ & $57.58 \pm 17.52$ & $43.69 \pm 9.90$ & $49.63 \pm 3.92$ & 0.422 \\
MDA $(\mathrm{nmol} / \mathrm{mg})$ & $0.87 \pm 0.22$ & $1.25 \pm 0.25$ & $1.84 \pm 0.36^{*}$ & $1.30 \pm 0.23 \#$ & 0.001 \\
\hline
\end{tabular}

All data are expressed as the mean \pm SD. $p<0.05$ was considered as significant. * Significant when compared to Control and CAPE group. \# Significant when compared to CP group. Abbreviations: CP, cisplatin; CAPE, caffeic acid phenethyl ester; SOD, superoxide dismutase; CAT, catalase; MDA, malondialdehyde.

\section{DISCUSSION}

The kidney is a vital organ in the body, but it is also a major target organ for toxic drugs transmitted by bloodstream because of its high blood supply. Drug exposure-induced nephrotoxicity is one of the most common health complication (Mehta et al., 2007). Thus, the investigation of the new strategies to alleviate nephrotoxicity constitutes an active research area. In addition to focusing on drug delivery and researching safer therapeutics, determining the combinatorial strategies of nephrotoxic drugs and therapeutics is considered the ideal treatment for many kidney injuries induced by nephrotoxic agents such as CP, which is an antineoplastic chemotherapeutic. Many different therapeutics including antioxidants, nitric oxide modulators and anti-apoptotic agents have been investigated for their protective and therapeutic effects on CP induced nephrotoxicity (Ali \& Al Moundhri, 2006). Nowadays, naturally occurring dietary substances which have strong antioxidant properties is considered as a promising candidates for attenuation of CP induced nephrotoxicity (Naqshbandi et al., 2012, 2013; Abdel Moneim et al., 2014;). CAPE is an active phenolic component of propolis in the hives of honeybees and it has several important physiological activities such as antitumoral, antiproliferative, anti-inflammatory, antineoplastic, and antioxidant properties (Burdock). Many studies have reported that $\mathrm{CP}$ administrations cause a serious kidney damage by inducing tubular epithelial injury, changes in glomerular space and infiltration of the inflammatory cells (Abd El-Kader \& Taha, 2020; Sadeghi et al.). Moreover, several studies have reported that CAPE ameliorates the kidney damage induced by antineoplastic chemotherapeutics such as CP (Ozen et al.; Akyol et al., 2014). In this study, we aimed to investigate the potential therapeutic effects of CAPE on CP-induced nephrotoxicity via focusing on oxidative stress and inflammation in rats. According to our histopathological examination, we observed that $\mathrm{CP}$ induced a serious kidney damage by causing glomerular degeneration, microvilli reduction and tubular dilatation. However, in the $\mathrm{CP}+\mathrm{CAPE}$ group, kidney tissues showed an improvement in terms of glomerular degeneration, microvilli reduction, and tubular dilatation. These results suggest that CAPE applications alleviate $\mathrm{CP}$-induced kidney damage and help to restore the normal histological appearance of kidney tissue. 
Oxidative stress is induced by excessive production of ROS that can attack the DNA, oxidize it and trigger the apoptotic pathways (Al-Dalaen \& Al-Qtaitat). Moreover, oxidative stress leads to lipid peroxidation (LPO) of the cell membranes. The endogenous antioxidant system including SOD and CAT enzymes aims to neutralize ROS (Kumar et al.). Many studies have reported that $\mathrm{CP}$ inhibits the antioxidant defense system by causing a significant decrease in the tissue SOD and CAT levels, and finally causes LPO by inducing the overexpression of MDA in the kidney tissue (Abdel-Daim et al., 2020; Sioud et al., 2020). In the present study, we showed that $\mathrm{CP}$ caused significant changes in the tissue SOD, CAT and MDA levels. According to our biochemical results, kidney tissue SOD and CAT levels tended to decrease in CP group compared to Control and CAPE group. Moreover, kidney tissue SOD and CAT levels in the $\mathrm{CP}+\mathrm{CAPE}$ group were higher than those in $\mathrm{CP}$ group. We suggest that CAPE administrations ameliorated the inhibition of the antioxidant defense system in the kidney tissue via increasing the expressions of SOD and CAT enzymes. Additionally, we observed that $\mathrm{CP}$ significantly increased the LPO in the kidney tissue via inducing the overexpression of the MDA enzyme. However, after CAPE administrations we noticed that CAPE significantly decreased the kidney tissue MDA levels in the CP+CAPE group. Based on these results, we suggest that CAPE significantly reduces the LPO caused by oxidative stress via reducing MDA levels in kidney tissue. In light of our biochemical results, we can say that CAPE administrations attenuated the detrimental effects of oxidative stress and LPO by ameliorating the changes in the SOD, CAT and MDA enzyme levels in the kidney tissue.

Excessive formation of ROS, the inhibition of the antioxidant defense system and LPO of bio membranes may cause the upregulation of inflammatory pathways and excessive releasing of pro- and anti-inflammatory cytokines such as TNF- $\alpha$ and IL-6 (Noronha et al.). Several studies have reported that $\mathrm{CP}$ administrations cause a significant inflammation by inducing the overexpression of TNF- $\alpha$ and IL-6 in the kidney tissue (Liu et al.; Tomar et al., 2020). In this study, we investigated the changes in the TNF- $\alpha$ and IL-6 expression levels in the kidney tissue immunohistochemically. According to our immunohistochemical results, the expression levels of TNFa and IL-6 significantly increased in the CP group compared to Control and CAPE group, indicating a serious inflammation in the kidney tissue. On the other hand, the significant decrease in the expression levels of the TNF- $\alpha$ and IL- 6 were observed in the CP+CAPE group compared to $\mathrm{CP}$ group. These results suggest that $\mathrm{CAPE}$ inhibits the inflammation induced by $\mathrm{CP}$ by suppressing the overexpression of the TNF- $\alpha$ and IL- 6 , which are inflammatory cytokines.
As a result, our study showed that CAPE ameliorates the detrimental effects of the oxidative stress, lipid peroxidation and inflammation induced by $\mathrm{CP}$ via alleviating the changes in the kidney tissue SOD, CAT, MDA, TNF-a and IL-6 levels because of its antioxidant and antiinflammatory properties. We suggest that CAPE can be used as a therapeutic agent to reduce the side effects of CP chemotherapy. Our study will support the new studies for the evaluation of CAPE in alternative treatments in chemotherapy-induced nephrotoxicity.

\section{FUNDING}

The author(s) disclosed receipt of the following financial support for the research, authorship, and/or publication of this article: This study has been supported by a grant from the research and technology department of Erciyes University with grant number TYL-2015-5948.

CEYLAN, T.; KAYMAK, E.; AKIN, A. T. \& YAKAN, B. LOS efectos de mejora del éster fenetílico del ácido cafeico en la nefrotoxicidad inducida por cisplatino: Evaluación del estrés oxidativo y la inflamación. Int. J. Morphol., 39(2):612-618, 2021.

RESUMEN: El objetivo de este estudio fue determinar los posibles efectos terapéuticos de éster fenetílico del ácido cafeico (EFAC) en la nefrotoxicidad inducida por cisplatino (CP) en ratas. El CP es un quimioterapéutico antineoplásico utilizado para el tratamiento de muchos tipos de cáncer, sin embargo sus aplicaciones pueden inducir nefrotoxicidad. El EFAC es un componente activo del propóleo y tiene varias actividades fisiológicas importantes. Para el estudio las ratas se dividieron en cuatro grupos: Control, EFAC (10 $\mu \mathrm{mol} / \mathrm{kg} / \mathrm{ip}), \mathrm{CP}$ ( $7 \mathrm{mg} / \mathrm{kg} / \mathrm{ip})$ y $\mathrm{CP}+\mathrm{EFAC}(7 \mathrm{mg} / \mathrm{kg} / \mathrm{ip}, \mathrm{CP}$ y $10 \mu \mathrm{mol} / \mathrm{kg} / \mathrm{ip}$, EFAC) Después de las administraciones, se sacrificaron los animales y se extrajeron los tejidos renales. Se evaluaron los cambios histopatológicos y se realizó inmunotinción de TNF- $\alpha$ e IL-6. Además, los niveles tisulares de SOD, CAT y MDA se midieron mediante un ensayo ELISA para evaluar el estrés oxidativo y la peroxidación lipídica. El grupo CP mostró deterioro histopatológico en comparación con el grupo Control y el tratamiento con EFAC atenuó este daño. En comparación con el grupo de control y EFAC, se observó un aumento en las inmunorreactividades de TNF- $\alpha$ e IL- 6 y los niveles de MDA en el tejido en el grupo de $\mathrm{CP}$, mientras que se detectó una disminución en los niveles de SOD y CAT en los tejidos. Además, se observó una mejora en el CP + EFAC en comparación con el grupo CP. Sugerimos que EFAC puede utilizarse como agente terapéutico para atenuar los efectos tóxicos del cisplatino, gracias a sus propiedades antioxidantes y antiinflamatorias.

PALABRAS ClaVE. Cisplatino; Éster fenetílico del ácido cafeico; Inflamación; Estrés oxidativo. 


\section{REFERENCES}

Abd El-Kader, M. \& Taha, R. I. Comparative nephroprotective effects of curcumin and etoricoxib against cisplatin-induced acute kidney injury in rats. Acta Histochem., 122(4):151534, 2020.

Abdel Moneim, A. E.; Othman, M. S. \& Aref, A. M. Azadirachta indica attenuates cisplatin-induced nephrotoxicity and oxidative stress. Biomed. Res. Int., 2014:647131, 2014.

Abdel-Daim, M. M.; Abdel-Rahman, H. G.; Dessouki, A. A.; El-Far, A. H.; Khodeer, D. M.; Bin-Jumah, M.; Alhader, M. S.; Alkahtani, S. \& Aleya, L. Impact of garlic (Allium sativum) oil on cisplatin-induced hepatorenal biochemical and histopathological alterations in rats. Sci. Total Environ., 710:136338, 2020.

Akyol, S.; Ugurcu, V.; Altuntas, A.; Hasgul, R.; Cakmak, O. \& Akyol, O. Caffeic acid phenethyl ester as a protective agent against nephrotoxicity and/or oxidative kidney damage: a detailed systematic review. ScientificWorld Journal, 2014:561971, 2014.

Al Fayi, M.; Otifi, H.; Alshyarba, M.; Dera, A. A. \& Rajagopalan, P. Thymoquinone and curcumin combination protects cisplatin-induced kidney injury, nephrotoxicity by attenuating NFkB, KIM-1 and ameliorating Nrf2/HO-1 signalling. J. Drug Target., 28(9):913-22, 2020.

Al-Dalaen, S. M. \& Al-Qtaitat, A. I. Review article: Oxidative stress versus antioxidants. Am. J. Biosci. Bioeng., 2(5):60-71, 2014.

Ali, B. H. \& Al Moundhri, M. S. Agents ameliorating or augmenting the nephrotoxicity of cisplatin and other platinum compounds: a review of some recent research. Food Chem. Toxicol., 44(8):1173-83, 2006.

Burdock, G. A. Review of the biological properties and toxicity of bee propolis (propolis). Food Chem. Toxicol., 36(4):347-63, 1998.

Dasari, S. \& Tchounwou, P. B. Cisplatin in cancer therapy: molecular mechanisms of action. Eur. J. Pharmacol., 740:364-78, 2014.

Hanif, M. \& Hartinger, C. G. Anticancer metallodrugs: where is the next cisplatin? Future Med. Chem., 10(6):615-7, 2018.

Howlader, N.; Noone, A. M.; Krapcho, M.; Miller, D.; Brest, A.; Yu, M.; Ruhl, J.; Tatalovich, Z.; Mariotto, A.; Lewis, D. R.; et al. (Eds.). SEER Cancer Statistics Review, 1975-2016. Bethesda, National Cancer Institute, 2019. Available from: https://seer.cancer.gov/csr/1975_2016/

Ismail, R. S.; El-Awady, M. S. \& Hassan, M. H. Pantoprazole abrogated cisplatin-induced nephrotoxicity in mice via suppression of inflammation, apoptosis, and oxidative stress. Naunyn Schmiedebergs Arch. Pharmacol., 393(7):1161-71, 2020.

Karabulut, D.; Ulusoy, H. B.; Kaymak, E. \& Sönmez, M. F. Therapeutic effects of pentoxifylline on diabetic heart tissue via NOS. Anatol. J. Cardiol., 16(5):310-5, 2016.

Kohsaka, T.; Minagawa, I.; Morimoto, M.; Yoshida, T.; Sasanami, T.; Yoneda, Y.; Ikegaya, N. \& Sasada, H. Efficacy of relaxin for cisplatininduced testicular dysfunction and epididymal spermatotoxicity. Basic Clin. Androl., 30:3, 2020.

Kumar, A.; Sasmal, D. \& Sharma, N. An insight into deltamethrin induced apoptotic calcium, p53 and oxidative stress signalling pathways. Toxicol. Environ. Health Sci., 7(1):25-34, 2015.

Lampe, H.; Horwich, A.; Norman, A.; Nicholls, J. \& Dearnaley, D. P. Fertility after chemotherapy for testicular germ cell cancers. J. Clin. Oncol., 15(1):239-45, 1997.

Liu, S.; Zhang, X. \& Wang, J. Isovitexin protects against cisplatin-induced kidney injury in mice through inhibiting inflammatory and oxidative responses. Int. Immunopharmacol., 83:106437, 2020.

Lu, Y. \& Cederbaum, A. I. Cisplatin-induced hepatotoxicity is enhanced by elevated expression of cytochrome P450 2E1. Toxicol. Sci., 89(2):515-23, 2006

Mehta, R. L.; Kellum, J. A.; Shah, S. V.; Molitoris, B. A.; Ronco, C.; Warnock, D. G.; Levin, A. \& Acute Kidney Injury Network. Acute Kidney Injury Network: report of an initiative to improve outcomes in acute kidney injury. Crit. Care, 11(2):R31, 2007.
Melli, G.; Taiana, M.; Camozzi, F.; Triolo, D.; Podini, P.; Quattrini, A.; Taroni, F. \& Lauria, G. Alpha-lipoic acid prevents mitochondrial damage and neurotoxicity in experimental chemotherapy neuropathy. Exp. Neurol., 214(2):276-84, 2008.

Naqshbandi, A.; Khan, M. W.; Rizwan, S.; Rehman, S. U. \& Khan, F. Studies on the protective effect of dietary fish oil on cisplatin induced nephrotoxicity in rats. Food Chem. Toxicol., 50(2):265-73, 2012.

Naqshbandi, A.; Rizwan, S. \& Khan, F. Dietary supplementation of flaxseed oil ameliorates the effect of cisplatin on rat kidney. J. Funct. Foods, 5(1):316-26, 2013

Noronha, I. L.; Niemir, Z.; Stein, H. \& Waldherr, R. Cytokines and growth factors in renal disease. Nephrol. Dial. Transplant, 10(6):775-86, 1995.

Ozbilgin, S.; Ozkardesler, S.; Akan, M.; Boztas, N.; Ozbilgin, M.; Ergur, B. U.; Derici, S.; Guneli, M. E. \& Meseri, R. Renal ischemia/ reperfusion injury in diabetic rats: the role of local ischemic preconditioning. Biomed. Res. Int., 2016:8580475, 2016.

Ozen, S.; Akyol, O.; Iraz, M.; Sögüt, S.; Ozugurlu, F.; Ozyurt, H.; Odaci, E. \& Yildirim, Z. Role of caffeic acid phenethyl ester, an active component of propolis, against cisplatin-induced nephrotoxicity in rats. J. Appl. Toxicol., 24(1):27-35, 2004.

Patel, A. G. \& Kaufmann, S. H. How does doxorubicin work? eLife, 1:e00387, 2012

Quintanilha, J. C. F.; de Sousa, V. M.; Visacri, M. B.; Amaral, L. S.; Santos, R. M. M.; Zambrano, T.; Salazar, L. A. \& Moriel, P. Involvement of cytochrome P450 in cisplatin treatment: implications for toxicity Cancer Chemother. Pharmacol., 80(2):223-33, 2017.

Sadeghi, H.; Mansourian, M.; Kokhdan, E. P.; Salehpour, Z.; Sadati, I.; Abbaszadeh-Goudarzi, K.; Asfaram, A. \& Doustimotlagh, A. H. Antioxidant and protective effect of Stachys pilifera Benth against nephrotoxicity induced by cisplatin in rats. J. Food Biochem. 44(5):e13190, 2020.

Santos, N. A. G.; Catão Bezerra, C. S.; Martins, N. M.; Curti, C.; Bianchi, M. L. P. \& Santos, A. C. Hydroxyl radical scavenger ameliorates cisplatin-induced nephrotoxicity by preventing oxidative stress, redox state unbalance, impairment of energetic metabolism and apoptosis in rat kidney mitochondria. Cancer Chemother. Pharmacol., 61(1):14555,2008

Sioud, F.; Ben Toumia, I.; Lahmer, A.; Khlifi, R.; Dhaouefi, Z.; Maatouk, M.; Ghedira, K. \& Chekir-Ghedira, L. Methanolic extract of Ephedra alata ameliorates cisplatin-induced nephrotoxicity and hepatotoxicity through reducing oxidative stress and genotoxicity. Environ. Sci. Pollut. Res. Int., 27(11):792-12801, 2020.

Tomar, A.; Kaushik, S.; Khan, S. I.; Bisht, K.; Nag, T. C.; Arya, D. S. \& Bhatia, J. The dietary isoflavone daidzein mitigates oxidative stress, apoptosis, and inflammation in CDDP-induced kidney injury in rats: Impact of the MAPK signaling pathway. J. Biochem. Mol. Toxicol., 34(2):e22431, 2020.

\section{Corresponding author: \\ Tayfun Ceylan \\ Cappadocia University \\ Cappadocia Vocational School \\ Department of Medical Services and Technique \\ Pathology Laboratory Techniques Pr. \\ Nevsehir \\ TURKEY}

E-mail: tyf.ceylan@gmail.com

Received: $14-05-2020$

Accepted: 29-12-2020 